\title{
PLAYING WITH IMAGES: THE VISUALIZATION OF THE OTHER IN HINDU-BALINESE RELIGION
}

\author{
Volker Gottowik \\ Goethe University, Frankfurt \\ $<$ Gottowik@em.uni-frankfurt.de>
}

\section{Introduction}

In the context of a modern theory of images, the question has been raised how the discursive paradigm and the visual paradigm, or the linguistic turn and the visual turn, relate to each other in the social and cultural sciences. In other words, has the "culture as text" metaphor been replaced or only supplemented by the "culture as image" metaphor? Do the two metaphors exclude or complement each other (see also Bachmann-Medick 2006: 351)? In the following, I seek to answer these questions by drawing on ethnographic experiences from my research in Indonesia.

In the twentieth century a restructuring of seeing and an increase in the significance of images took place in the wake of new possibilities of image production. Ever since, there has been a debate in the cultural sciences over the significance of the visual. Within this debate, three focal points were identified (see Rövekamp 2005), one on the relationship of seeing to the other senses (hearing, touching, etc.), the second on the relationship between seeing and knowledge, and the third on the relationship between seeing and language (image and word). The central question here is whether semiotics as a theory of signs, which was actually developed with reference to language, is also applicable to the field of the visual. In other words, can an image be fully grasped with the categories of semantics, pragmatics and syntax, or does it have specific properties that extend beyond semiotics (see Rövekamp 2005)?

The positions taken within this debate over the visual depend 
particularly on what is meant by an image. Against this background, reference should be made to the distinction between narrow and extended pictorial or image concepts.

The German philosopher Klaus Sachs-Hombach explicitly advocates a "narrow pictorial concept" (SachsHombach 2003: 52) which is at the same time a semiotic concept of the image: "(...) everything that is said about signs in general also applies to images, in particular that they have internal structures (syntax), that they refer to something or relate to something (semantics) and that they are embedded in broader sign-action contexts [Zeichenhandlungskontexte] (pragmatics)" (Sachs-Hombach 2003: 73, my translation).

Given the similarities between image and word or picture and language postulated here, Sachs-Hombach comes to the following definition: "Pictures in this narrow sense can be characterized as artificially produced or edited, flat and relatively durable objects that are usually used within a communicative act to illustrate real or even fictitious issues [reale oder auch fiktive Sachverhalte]" (Sachs-Hombach 2003: 74, my translation).

This conventional or narrow pictorial concept, which revolves around such attributes as "flat", "artificial" and "permanently," explicitly excludes particular images, for example ideal images, aural images and mirror images, but also pictorial works [Bildwerke] such as sculptures or figurative representations (see SachsHombach 2003: 50f.). However, this narrow pictorial concept, which sees an image primarily as an illustration, is hardly productive for an anthropological investigation of, for example, ritual or theater.

In seeking for a less narrow pictorial concept that is not tied to categories such as "flatness," the considerations of the art historian Hans Belting are of particular interest. In his work Bild-Anthropologie (2001), ${ }^{1}$ he gives the following definition: "An 'image' is more than a product of perception. It emerges as the result of a personal or cultural symbolization. Anything that enters the eye or the inner eye can be clarified as an image or transformed into an image. Therefore, the image concept, if taken seriously, can ultimately only be anthropological. We live with images and comprehend the world in images" (Belting 2001: 11, my translation).

On the basis of this extended image concept, an image is no longer just an illustration but is open with respect to perception as a social and cultural practice. This image concept is anthropological as it is based on the premise that human beings act medially and experience themselves

\footnotetext{
1 This work has been revised, but only partly translated as An Anthropology of Images: Picture, Medium, Body, Princeton and Oxford: Princeton University Press 2011. Therefore all quotes are my translations from the German original.
} 
medially (see Belting 2001: 14). It is also post-semiotic in that it replaces the question of what a picture means by the question of how a picture produces or attains meaning (Belting 2001: 12, 15). Finally, partly following Thomas Mitchell's Iconology (1986), this extended notion of the image draws a distinction between the image as an icon and the picture as a medium (analogous to parole and langue), which is of central importance. It is central because only this distinction makes it possible to explore different media (painting, sculpture, dance, ritual) with regard to the images they create.

This extended image concept is of epistemological and methodological interest to anthropology, as it is aimed at processes of "image generation in social space": theater, cult, initiation and obsession are conceptualized as "live performances of a different kind of image", while ritual, masquerade and dance become "imaging processes" which aim at the "collective imaginary" and appeal to the entire human being in its corporeality, that is, to all its senses (see Belting 2001: 12, 51f.).

The ability to relate rituals as an imaging medium to pictures as a performative medium and to investigate their internal dynamics is the claim made by Christoph Wulf and Jörg Zirfas in their Iconology of the Performative (Wulf and Zirfas eds. 2005). This approach emphasizes the connection between image and performativity, that is, the iconic meaning of the performative and the performative character of images. With regard to the relationship between image and body, they emphasize:

"Images are physically experienced. It is not just the eyes that make contact with the image and produce an image - the entire human body experiences the reality of images" (Wulf and Zirfas 2005: 15, my translation).

On the pages that follow, I would like to apply this extended image concept to the ethnographic example of a pair of masks that are at the center of various rituals in southern Bali. The ritual actors are members of Agama Hindu Bali, the Hindu-Balinese religion.

\section{Masks as medium and image: an ethnographic example}

The masks I introduce here form part of two huge sacred figures called Barong Landung. This pair consists of a black man and a white woman, and on particular occasions they go out and perform in the streets of South Bali (see also Gottowik 2005, 2008). In line with the extended image concept and the "iconology of the performative" mentioned above, I will analyze these masks as a medium capable of producing particular images and their ritual performance as an "imaging process" that appeals to all the senses.

However, when the ritual actors are asked whom these two figures represent, 
they give only brief answers. They state that the white woman is a Chinese woman who has married the man by her side. The identity of the man, on the other hand, remains strangely indefinite and oscillates between an Indian prince, a Balinese king and a powerful demon. According to the only reliable statement about this heterosexual pair of sacred figures, the white mask represents a Putri Cina, a Chinese woman.

But why is there a mask in Bali that represents a Chinese woman? It seems likely that the representation of this woman in the medium of masks refers to the existence of a significant Chinese minority in Indonesia. However, in the history of Indonesia members of this minority have repeatedly fallen victim to violent attacks and bloody pogroms. Accordingly the ethnic Chinese in Indonesia are sometimes referred to as "the Jews of the East" (see e.g. Krause 1922: 39). Since they were not allowed to acquire land they had to settle in the city, where they became active, some of them quite successfully, in trade and money-lending. However, in their role as traders and money-lenders, they repeatedly became victims of mass violence, the last massacres committed against them having occurred during the 1998 riots that forced Suharto to step down as president of the Republic of Indonesia (see Gottowik 2014: 231234).

Against the background of these historical events, the two Barong
Landung masks can be used as a medium not only to comment on these events, but also to make the existence of a significant Chinese minority in present-day Bali a topic of collective thinking and consent-building. And indeed, as will be shown later, the two masks are deployed "within a communicative act to illustrate real or even fictitious issues" (Sachs-Hombach 2003: 74, my translation). In this context, it is not only the dialogues that are spoken through the mask that are interesting, but also the images that are created when the black man and the white woman parade through the streets of South Bali and dance with each other in public. For these pictures not only illustrate the relationships between Hindu Balinese and ethnic Chinese in Bali, they also shape them in so far as they are both a "model of" and "a model for" such a relationship. ${ }^{2}$

It should be noted that the two Barong Landung figures, who always appear together in public, are involved in various myths and legends. However, these to some extent contradictory narratives are only known to a few specialists. The vast majority of the ritual actors who kneel before them to sacrifice and pray on festive occasions such as Hari Raya Galungan and Hari Raya Kuningan know little more than the following details: The Chinese

2 The concept of symbol systems as "model of" and "model for" was developed by Clifford Geertz in his "Religion as a Cultural System" (Geertz 1970a: 93-95, 118). 
woman was married to the man by her side, but, it is frequently added, she could not give birth to a child. Occasionally it is said that she is a Buddhist, whereas her husband is a Hindu. But as these details are largely contentious, the myths and legends associated with this unequal pair of masks play only a subordinate role for the ritual actors, who are hardly aware of their contradictory nature. However, they are very much aware of the visual appearance of the two sacred figures and the different ritual contexts in which they perform. While the myths are hardly known to anyone, every child in the south of Bali can describe the distinctive look of Barong Landung masks. In other words, almost all Balinese have an image of them in their minds, but hardly anyone has a text.

Although each pair of Barong Landung masks looks a little different, there are recurring features that characterize the roughly one hundred examples of them in South Bali. Thus the woman has a protruding forehead and chin (giving her a concave profile that reminds of a new moon), while the man has a rather receding forehead and chin; the woman's nose is narrow and straight, while the man's nose is round and bulbous; the woman's lips are finely drawn and seem to indicate an enigmatic smile, while the man has his mouth open and seems to be baring his teeth; she wears a double ikat cloth (with a pattern from the village of

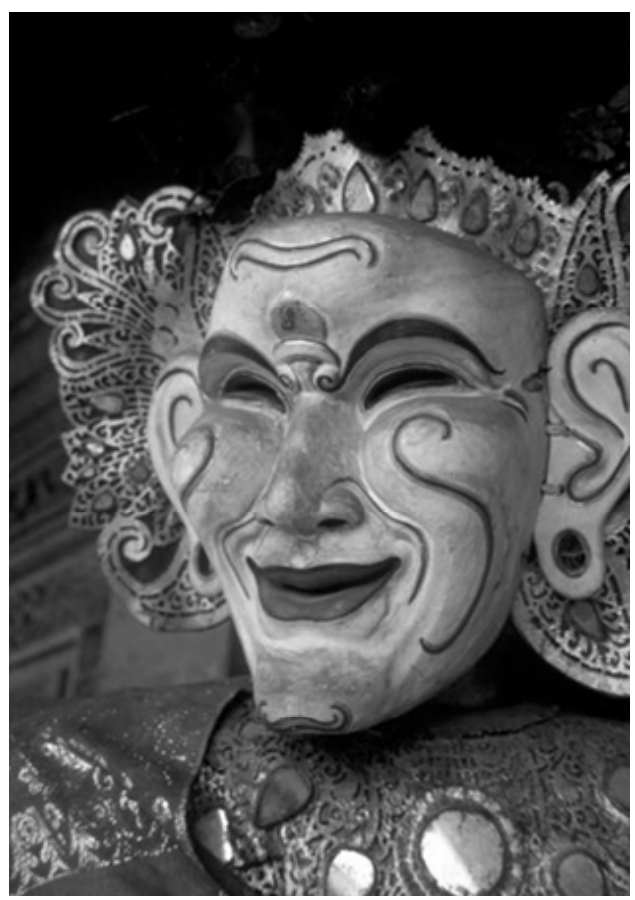

Figure 1. The mask of the female character of Barong Landung; picture by Volker Gottowik (1998)

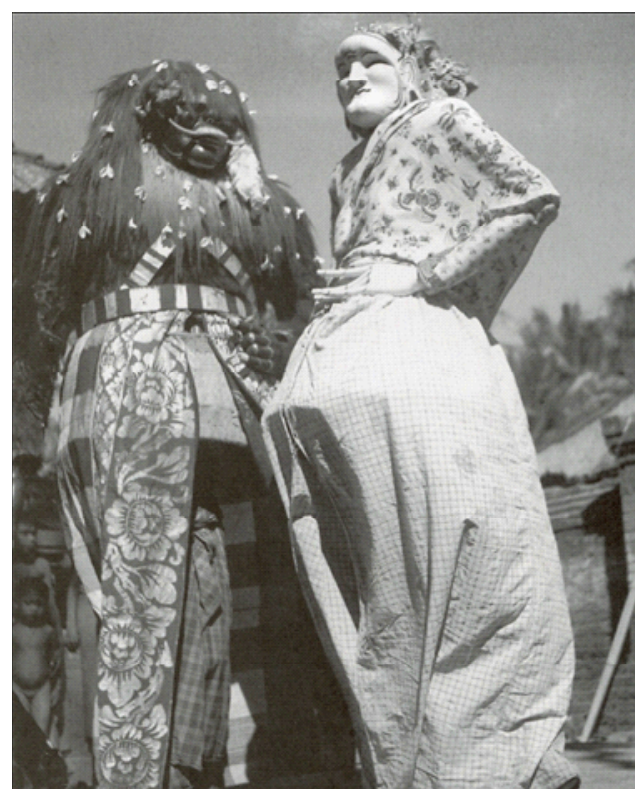

Figure 2. Historical picture of a Barong Landung couple by Beryl de Zoete and Walter Spies (1936) 
Geringsing), while he wears a kris (a dagger with a wavy blade); ${ }^{3}$ she has signs of female senility, her long hair being light in color (suggesting gray hair in the Southeast Asian context), her bare breasts are hanging down, while in sharp contrast the man stands for virility, obviously being full of life and vigor, as his flowing hair and his black body hair clearly indicate.

According to an iconography that takes into account all the components listed above, the two Barong Landung figures are juxtaposed to one another in a way that occurs widely in Indonesia: This is the juxtaposition between kasar and halus, between a rude character and a noble character or, figuratively speaking, between nature and culture. Interestingly enough, it is not the woman who embodies nature in this context but the man, while she stands for culture, expressed in her sophisticated appearance, which is visible to everyone.

What is visualized with the two Barong Landung figures, then, is the difference between nature and culture, young and old, man and woman sexually connoted opposites that must be periodically overcome in order to keep the cycle of life going. However, this preliminary interpretation of this unequal pair derives from an iconography which is based exclusively

3 Both attributes, the ikat cloth and the kris dagger, are considered to be heirlooms (pusaka) and therefore as magically powerful. When the dagger is placed on or in the cloth, together they symbolically represent marriage or sexual union. on form, materials and color. This rather conventional approach should be distinguished from that of the "iconology of the performative," which focuses rather on the images generated by these figures. In this context it would be important to note, for example, how these figures interact with each other when they perform in public. In anticipation of my further remarks, I may say that they occasionally dance in the streets of southern Bali in a way that some Hindu-Balinese call porno sekali (very pornographic).

Even in respect of the narrow image concept, introduced at the beginning, no religion can manage without visual representations. In other words, there is no religious belief that completely renounces visualization. It is not only Hinduism in Bali or India that makes use of visual representations: even Islam, the epitome of an iconoclastic belief system, has depictions of, for example, Mecca and Medina that visualize these sacred sites. Other non-iconic visualizations include the Holy Cross in Christianity, the Star of David in Judaism, the linga and yoni in Hinduism, and Yin and Yang in Taoism, not to mention the figurative representations of traditional belief systems, which the so-called high religions usually denounce as idolatry. The image - and in an expanded sense, the ritual as an imaging medium - is a fundamental, liturgical aspect of all faiths (see Morgan 2005: 11). However, 
what are the peculiar religious functions of iconic representations in ritual contexts and visual practices?

When rituals are imaging processes, everything that is said about the function and meaning of rituals can also be related to images in the ritual context: they arrange space and time, foster community and solidarity, enable communication with otherworldly powers, visualize mythical and historical events etc. (see Morgan 2005: $55 \mathrm{ff}$.). The two Barong Landung figures are also productive in this context. However, they do not linearly retrieve the points listed here, as I had to do line by line, but convey them to the ritual actors by means of a single glance. Therefore, as an imaging medium they are a particularly impressive means of organizing experience and providing orientation. As is well known, the whole is more than the sum of its parts, and so the overall visual impression that is received by the viewer's entire body goes far beyond what even the most detailed textual description is able to convey.

\section{The ambiguity of images and their interpretation}

The Hindu-Balinese religion is among those traditional belief systems that have neither a well-defined dogma nor a revealed scripture. One becomes a Hindu by birth. Mission and conversion, which alone make a creed necessary, are not provided for and, in principle, do not take place. The mediation and appropriation of this largely nonscriptural belief system happens primarily through ritual practice. In other words, its religious traditions are transmitted, communicated and commented on in a largely performative way and in the context of a locally varied (lain desa, lain adat) and contextual variable (desa, kala, patra) ritual practice. The wide absence of dogma (orthodoxy) and the emphasis placed on performance (orthopraxis) gives the impression of a barely standardized, extremely flexible, even tolerant belief system that is constantly renewing itself in its rituals, celebrations and festivals. This festive culture has been preserved into the present in so far as spiritual and cosmological ideas are still not primarily passed on a theoretical content, but are conveyed performatively in the framework of elaborate rituals (see Hornbacher 2008). In Bali, ritual practice includes performances like Wayang Kulit, Wayang Wong, Topeng, Arja and Calonarang, which oscillate between masquerade and shadow play, operetta and folk theater (see Zoete/Spies 1938). Nevertheless, the use of western categories in describing the different genres should not obscure the fact that they are always ritual events: they take place in the temples or immediately in front of them, are held on certain holidays, and have the presence of a priest and the consent of other- 
worldly powers as a condition for their performance.

That these events are also enacted for the entertainment of tourists is a recent development that began to become significant only with the mass tourism of the 1970s. However, largely independent of these tourist performances, ritual practices continue to be performed at the village level, to which western visitors have barely gained access, though in fact they are open to everyone.

Part of this festive culture and its ritual practices are also the two Barong Landung figures. One of the numerous mythical-legendary narratives that are told about these two sacred figures is periodically staged and performed in the context of the dance drama Mesolah Ratu Gede. This dance drama is usually enacted during the transition from the dry season to the rainy season, when diseases pile up and endanger the wellbeing of the community. It is expected that the dance of the two figures will provide effective protection against, for example, influenza, colds and, formerly, cholera, illustrating the apotropaic character of these sacred figures.

The dance drama Mesolah Ratu Gede is about a Balinese ruler, Sri Jaya Pangus, who actually appears in the genealogies of Balinese royal families (babad). According to these babad, Sri Jaya Pangus was the head of a central Balinese royal house in the twelfth century. Since Balinese genealogies and chronicles trace only patrilineal descent, nothing is known about the numerous women whom these rulers usually called their own. This is different in respect to Mesolah Ratu Gede: Sri Jaya Pangus is said to have been married to the white lady by his side, a beautiful Chinese woman named Kang Cing Wi. ${ }^{4}$ The staging of their love story varies from village to village, from performance to performance, but the fact that the strange woman could not give birth to a child is always a central topic. In some performances, their relationship breaks down as the king takes another woman, while in others the two characters manage to solve the problem of their not having a child by mutual agreement. Central to all performances of Mesolah Ratu Gede is therefore a certain ambivalence stemming from the childlessness of this multicultural couple. In any case, all performances, regardless of how they deal with the couple's barrenness, end with their dance in front of a festive audience.

What western observers perceive during these dance performances first of all are the clumsy body movements and aesthetically unappealing dance steps of the two Barong Landung figures, which somewhat resemble a rustic form of the "Peking Opera". For Balinese observers, however, these dance steps appear very differently, as they regard the dance as

4 The female character of Barong Landung is always considered to be very beautiful due to her skin color which is described as light yellow (kuning langsar). 
porno sekali, "very pornographic".

There are several reasons for this perception of the dance. For one thing, social dances in Bali are traditionally almost unknown. An exception is Joged Bumbung, but female dancers who perform on a public stage are associated with prostitution. That a man and a woman rhythmically harmonize their body movements, as required by the dance of a couple, suggests other associations that specifically connote the sexual act.

Another reason for this dance being perceived as porno sekali is the series of offensive dance figures that characterize most performances. These dance figures include obscene gestures, such as an implied grip on the genitals of the dance partner, or an outstretched index finger, which suddenly stands out from the sarong of the male figure. ${ }^{5}$ The staging of this dance at the village level makes use of crude and in some ways unequivocal imagery.

However, the imagery is not self-evident: sexual acts performed in public spaces give rise, I think, to ideas of forced sexual acts. Indeed, the Chinese minority in Indonesia has not only been the target of bloody pogroms, Chinese women have also been victims of sexual assaults. However, the association, even the fear, that for the

5 Beryl de Zoete and Walte Spies who did research on Bali during the 1930s give the following description of this dance: "They carry on generally a kind of comic flirtation, with suggestive gestures, pretended kisses and caresses, his arm falling over her shoulder"(Zoete) Spies 1936: 114).
Chinese minority on Bali the masked figure personifying a Chinese woman was being humiliated in effigy proved to be unfounded. During the riots in May 1998, when hundreds of Chinese women became the victims of sexual violence in Jakarta and other major cities in Indonesia, those ethnic Chinese who could afford it fled to Singapore or Bali - because Singapore and Bali are considered comparatively safe for the Chinese minority in Indonesia (see also Gottowik 2010).

Another chain of associations related to sexual activity in public spaces carry the thoughts to fertility rituals. Indeed, the performance of the black-and-white figures was interpreted as a "love-dance" enriched with "agricultural courtship songs" by ethnographers like Beryl de Zoet and Walter Spies (cf. Zoete/Spies 1938: 113ff.) Other western ethnographers expressed their view that these folk songs "were originally connected with fertility rites" (Forman et al. 1983: 64) and emphasized the power of Barong Landung to "confer fertility on childless marriages" (Milner 1978: 63). However, the interpretation of the white lady as symbol of fertility and prosperity is misleading, since she has unmistakable features of "over-age femaleness". The woman with the gray hair and the emaciated breasts is obviously no longer at the peak of her reproductive capacity. Therefore, she seems hardly suitable for a fertility ritual. 
If one's own associations are misleading and the interpretations put forward by colleagues prove unconvincing, one reverts again to asking the ritual actors for explanations, even when most of them can't offer helpful exegetical commentary. According to them, the two sacred figures dance the way they do because they've always danced like that. Even the few local specialists can hardly say anything more than the Barong Landung figures dance like that because they are married to each other. Nonetheless, this interpretation gives a decisive hint of another possible interpretation of the images produced during Barong Landung performances.

No less a person than Arnold van Gennep pointed out that the sexual act in public space is often a ritual act of social union and collective identification. The ritually performed sexual act is thus not a symbolic expression of a fertility cult, as suggested by some western ethnographers, but a means of group formation aimed in particular at incorporating the stranger. It should therefore be considered a ritual of social integration (see Gennep 1960: 34).

However, the images produced by the two black-and-white masks do not depict the world even when they obviously refer to the existence of a Chinese minority on Bali, but are an essential means or cognitive tool used in interpreting it. They recall the story of a male Hindu who once married a female Buddhist and thus integrated her into the genealogy of Bali. In fact, many Balinese believe that their own religious beliefs and at least parts of their cultural traditions stem from just such a fusion of Chinese and Indian or Balinese influences. From this concept arises again a comparatively tolerant attitude between Hindus and Buddhists, which is described by some Balinese as the "Spirit of Balingkang" - Balingkang being the place in central Bali where the wedding between this black and white couple formerly took place. The two Barong Landung figures are also, one might say, a model of an interreligious and inter-cultural relationship that was established at the beginning of the historical period, as well as a model for such a relationship between Balinese and Chinese at the present time (cf. Geertz 1970a: 93-95, 118). However, since the couple could not have children, everyone has to decide for themselves if this was really a happy relationship or rather a failed one.

It contributes to the general ambiguity that the two figures occasionally argue loudly in public and insult each other. In some performances, however, they refer in their songs and dialogues to a Hindu-Balinese principle known as tatwam asi. Literally translated, this means "You are as I am", and when invoked by the Putri Cina, obviously a female stranger, it is condensed into an expressive image 
pointing to the fact that, beyond all superficial differences in sex, skin color, language, religion, etc., all human beings have a common basis that connects them. In Indonesian aku adalah kau is an invitation to rethink the relationship between different people and to discover the other in oneself.

\section{Playing with images and intercultural hermeneutics}

As sacred figures, the Barong Landung have no fixed significance, but are collective instruments of thought which allow the existential opposites of religion, culture, age, gender, etc. to be reconsidered. Some of the possible but also impossible results that can be achieved with these instruments have been addressed in the previous chapter. A final question with regard to the images produced by the Barong Landung is whether the pairing of an older, sophisticated woman and a younger, vital man and the periodic overcoming of the opposites they represent in a pornographic-looking dance is one of the many "tantric fragments" (Boon 1990: 158) that have been identified in Bali and Java. These fragments go back to a time when Tantrism as an influential current within Hinduism and Buddhism shaped religious beliefs and ritual practices, often with a focus on uniting opposites and forming a cosmic entity - not least the sexual differences in ritual coitus (see Bharati 1965; see also Gottowik
2018). Although Tantrism as an esoteric form of teaching with coordinated ritual practices has vanished on Bali and Java, "tantric fragments" may have survived not only in the linga and yoni cult, but also in the encounter between Barong Ket and Rangda (calonarang), the burial ceremony (ngaben) and, on Java, in courtly dances (bedhaya) and village cleansing rituals (bersih desa) (see Barth 1993: 262; Stephen 2010: 426ff.; Becker 1993: 138ff.; Roxas-Lim 1993: 136ff.).

The two Barong Landung figures can be localized in this context and then interpreted with regard to their possible Tantric content. After all, sexually connoted opposites are addressed here to "play" (bermain) with them, as some Balinese say, in both a performative and a cognitive sense. To use a phrase coined by Clifford Geertz (1970b), this is an example of "deep play" in so far as they play with representations of Balinese and Chinese characters and finally with the social relationship between them. It is a "play with fire" (Geertz 1970b: 432), as they play with what must be considered a forbidden relationship. Not only that, as some people say, Balinese should not marry Chinese - in this context the childlessness of the exemplary Barong Landung couple may be understood as a warning - but also, as is well known, a man should not marry a woman of higher social standing. However, the Putri Cina is just such a woman, as will 
be shown below.

In most known societies, for a woman to marry a socially superior man (hypergamy) does not pose a problem because the children they have together will receive the higher status of the man; in contrast, it is a problem almost everywhere in the world when a woman marries a socially low-ranking man (hypogamy) because in this case the relatively low status of their joint children will lower the social prestige of the woman's entire kinship group. Marriages under the latter conditions, which are manifest in a caste society such as Bali, are considered fragile or panas (hot) in so far as friction and conflict between these dissimilar partners are predictable.

The two Barong Landung figures also represent a "forbidden relationship", as the Putri Cina stands for the older and thus superior culture and the rustic man at her side for a comparatively young culture that has just started emancipating itself from its natural state. Given the impossibility of such a relationship, the same attributes are used in Bali as for a relationship that breaks the established marriage rules of a caste society.

The fact that a forbidden relationship is the subject of a "deep play", however, provides further arguments that it is possibly a tantric fragment. Finally, Tantrism, as handed down in the kekawin tradition, shows a particular preference not only for sexually connoted opposites, but also, in its left-hand variant, for forbidden relationships and sexual encounters between illicit partners (see Bharati 1965 and Rubinstein 2000: 108f.). It is not only a matter of overcoming these opposites, but also of violating social norms and values, which from a Tantric perspective can be both a condition for and an expression of a higher level of consciousness and a convergence with the Divine (moksa) (see Smith/ Woodward 2017; see also Gottowik 2018). Following this line of thought, the sexual activities of the Barong figures in public space, which place them outside the normal social order, appears as a demonstration of their magic power and spiritual superiority.

The different and in part contradictory interpretation of the Barong Landung figures presented here underlines the fact that the images that are produced performatively with them develop different meaningful references, depending on the contexts in which they are presented. Therefore the meaning of ritual performances and the images that are created by the interaction of the characters involved are anything but self-evident, but depend on the observer's framework and understanding. In other words, image perception is based on social conventions; seeing, observing and looking are culturally mediated practices. This also applies to the images that are produced with the 
two Barong Landung figures. Their relevance as instruments of collective thought arises precisely from their ambivalence, that is, from their openness to divergent statements and interpretations which, in the context of an "iconology of the performative," suggest the following questions: which images are produced, how are they interpreted, and in which ways do they affect culture and society?
In so far as images are as open in their meanings as words and deeds, they require a hermeneutic interpretation, which in anthropology has to be based on an intercultural hermeneutics. In view of this comprehensive task, the linguistic and iconic turn, like the "culture as text" metaphor and the "culture as image" metaphor, do not abolish each other, but complement each other beneficially.[]

\section{References}

Bachmann-Medick, Doris.2006:Culturalturns:NeuorientierungenindenKulturwissenschaften. Reinbek bei Hamburg: Rowohlt

Bharati, Aghenanda. 1965: The Tantric Tradition. London: Rider

Barth, Fredrik. 1993: Balinese Worlds. Chicago and London: The University of Chicago Press

Becker, Judith. 1993: Gamelan Stories: Tantrism, Islam and Aesthetics in Central Java. Arizona: Arizona State University

Belting, Hans. 2001: Bild-Anthropologie: Entwürfe für eine Bildwissenschaft. München: Fink. Revised and partly translated as: An Anthropology of Images: Picture, Medium, Body. Princeton and Oxford: Princeton University Press 2011

Boon, James. 1990: Affinities and Extremes: Crisscrossing the Bittersweat - Ethnography of East Indies History, Hindu Balinese Culture, and Indo-European Allure. Chicago and London: The University of Chicago Press

Forman, Werner/Rudolf Mrazek/Bedrich Forman. 1983: Bali: The Split Gate to Heaven. Ann Arbor: The University of Michigan Press

Geertz, Clifford. 1970a: Religion as a Cultural System. In: C. Geertz: The Interpretation of Cultures. New York: Basic Books 1970: 87-125

Geertz, Clifford. 1970b: Deep Play: Notes on the Balinese Cockfight. In: C. Geertz: The Interpretation of Cultures. New York: Basic Books 1970: 412-454

Gennep, Arnold van. 1960: The Rites of Passage. London: Routledge \& Kegan Paul

Gottowik, Volker. 2005: Die Erfindung des Barong: Mythos, Ritual und Alterität auf Bali. Berlin: Reimer

Gottowik, Volker. 2008: The Barong wants to go out again: Krisis moneter and the Resurgence of Rituals in Indonesia. In: Austrian Journal of South-East Asian Studies 2008: 1(2): 95-104 (also Online-Publication)

Gottowik, Volker. 2010: Transnational, Translocal, Transcultural: Some Remarks on the Relations between Hindu-Balinese and Ethnic Chinese in Bali. In: Sojourn. Journal of 
Social Issues in Southeast Asia 2010: 25(2): 178-212

Gottowik, Volker. 2014: Ethnicity and Violence on Bali: and what Barong Landung says about it. In: Volker Gottowik (ed.): Dynamics of Religion in Southeast Asia: Magic and Modernity. Amsterdam: Amsterdam University Press 2014: 217-236.

Gottowik, Volker. 2018: Pilgrims, Prostitutes and Ritual Seks: Heterodox Ritual Practices in the Context of the Islamic Veneration of Saints in Central Java. In: Bijdragen tot de Taal-, Land- en Volkenkunde 2018: 174: 393-421

Krause, Gregor. 1922: Bali: Volk, Land, Tänze, Feste, Tempel (mit Beiträgen von K. With und E. Fuhrmann). Hagen: Folkwang, 2. Auflage in einem Band

Hornbacher, Annette. 2005: Zuschreibung und Befremden: postmoderne Repräsentationskrise und verkörpertes Wissen im balinesischen Tanz. Berlin: Reimer

Milner, G. B. 1978: Natural Symbols in Southeast Asia. London: SOAS

Mitchell, Thomas. 1986: Iconology. Image, Text, Ideology. Chicago and London: The University of Chicago Press

Morgan, David. 2005: The Sacred Gaze: Religious Visual Culture in Theory and Practice. Berkeley et al.: University of California Press

Rövekamp, Elke. 2005: Das unheimliche Sehen - das Unheimliche sehen. Zur Psychodynamik des Blicks. Berlin: Dissertation Freie Universität Berlin. Online Publication: https:// refubium.fu-berlin.de/handle/fub188/4621

Roxas-Lim, Aurora. 1993: Caves and Bathing Places in Java as Evidence of Cultural Accommodation. In: Asian Studies 1993: 21: 107-175

Rubinstein, Raechelle. 2000: Beyond the Realm of the Senses: The Balinese Ritual of Kakawin Composition. Leiden: KITLV Press

Sachs-Hombach; Klaus. 2003: Das Bild als kommunikatives Medium: Elemente einer allgemeinen Bildwissenschaft. Köln: von Halem

Smith, Bianca J./Mark Woodward. 2016: Magico-Spiritual Power, Female Sexuality and Ritual Sex in Muslim Java: Unveiling the kesekten of Magical Women. In: Australian Journal of Anthropology 2016: 27: 317-332

Stephen, Michele . 2010: The Yogic Art of Daying, Kundalini Yoga, and the Balinese pitra yadnya. In: Bijdragen tot de Taal-, Land- en Volkenkunde 2010: 166: 426-474

Wulf, Christoph/Jörg Zirfas (eds.). 2005: Ikonologie des Performativen. München: Fink

Zoete, Berryl de/Walter Spies. 1938: Dance and Drama in Bali. London: Faber and Faber 